\title{
THE AMBIVALENT LANDSCAPE OF CHRISTIAN CORINTH: THE ARCHAEOLOGY OF PLACE, THEOLOGY, AND POLITICS IN A LATE ANTIQUE CITY
}

\author{
William Caraher
}

\begin{abstract}
Introduction
The political, economic, and ecclesiastical position of Corinth during the middle decades of the 6th century CE created an environment with the potential for dynamic contrasts between Corinthian residents and imperial authority. Corinth and its territory represented a liminal zone between the more prosperous east and the less stable west, stood amidst conflicting political and ecclesiastical jurisdictions during shifts in the nature of imperial authority, and endured a systematic campaign of external investment by the ambitious and expansionistic emperor Justinian I (527-565 CE), who sought not only to expand imperial power institutionally, but symbolically as well.

This chapter argues that the textual and archaeological evidence for imperial involvement in the Corinthia provides faint traces of what Elsner has called "internal friction" in the manifestation of imperial and Corinthian authority in the region. ${ }^{1}$ For Elsner, internal friction represented a cultural response to the presence of Romanness at the periphery of the empire. While Corinth is rarely regarded as a peripheral region, the political situation in the 6th century placed it at the limits of imperial control over ecclesiastical affairs, and the monumental building campaign attributed to the emperor Justinian suggests that the territory represented a significant focal point for imperial policy. At the same time, there were contemporary changes in the region that cannot be attributed directly to external involvement. The architectural and epigraphic evidence preserve traces of the kind of internal frictions that Elsner associated with practices of resistance and domination. Evidence for such practices suggests an ambivalence in Late Antique Corinth and the bishops of Illyricum
\end{abstract}

1 Elsner 2007, 255. 
toward imperial overtures throughout the 5th and into the 6th century. The methods employed by the emperor to project political and ecclesiastical power into the Corinthia suggest efforts both to entice and cow local residents into recognizing imperial authority. Exploring possible local responses to imperial projects cannot reveal whether local resistance or imperial policy carried the day in the 6th century, but it carves out interpretative space to consider economic, political, and even social inequality in the ancient world.

The historical circumstances of the $5^{\text {th }}$ and 6 th century in the Corinthia present a good vehicle for considering asymmetrical power relations in the region. The tensions between the political authority of the East and the religious authority of the West under Justinian presented a crucial phase in the conflicts that played out all across the Balkans beginning in the $5^{\text {th cen- }}$ tury. The political and ecclesiastical controversies that engulfed the Balkans began with the Acacian schism (484-519) which placed most of the bishops of Illyricum and Epiros at odds with the Patriarch and Emperor in Constantinople. ${ }^{2}$ The resolution of this conflict in 519 , shortly after the accession of Justin I, marked only a momentary break in the divisive politics of Chalcedon. The ascendance of Justinian and his well-documented and ambitious policies had a significant impact on the political and religious life of the empire, and Corinth did not escape the impact of these policies in its political position as the capital of Achaea and its ecclesiastical position as the seat of the powerful Bishop. ${ }^{3}$ The location of Corinth between East and West, imperial power and papal authority - provided a dynamic space for both resistance and accommodation.

My effort to excavate evidence for power relations and inequality in the Corinthia focuses on three relationships which capture the ambivalent nature of imperial authority in 6th-century Greece. The first section considers the relationship between ecclesiastical architecture and authority in the Corinthia. I argue that monumental religious architecture played an important role in projecting imperial power in the region and created a monumentalized discourse of political and religious authority, but also offered opportunities to resist this authority. The next section extends this discussion to consider how imperial efforts to project authority in the Corinthia shaped production, settlement, and fortification in the

2 For the best discussion of the Acacian Schism in Greece, see: Charanis 1974. See also Pietri 1984.

3 Rothaus 2000; Gritsopoulos 1972, 77-84. 
6th century. In this discussion, I focus on the impact that the monumentalized discourse of power and resistance had on the local economy and settlement as well as through the physical labor and experiences of ancient Corinthians. The final section of this chapter considers the theological aspect of the imperial presence in the region and argues that the expression of imperial policy manifested itself in a pair of theologically ambivalent texts and ritually-encoded architecture that manifest traces of internal friction between the goals of an imperial state and the understanding of power on the local level. The interplay between imperial patronage and the local response did not create a neatly organized binary between imperial power and local resistance. The interplay between evidence for local reception and imperial authority reinforced the ambivalent position of Corinth in the political and religious world of the 6th century situated between the crafty ambition of Justinian and persistent local interests.

\section{Monumentalizing the Discourse of Power}

Monumental architecture represents one of the most visible and significant means to project authority. ${ }^{4}$ Not only does monumental architecture make a visually impressive statement, but it also provides a space to articulate complex ideas, condition behavior, and generate emotional responses even in landscapes crowded with meaning. Monumental architecture has the additional benefit of being relatively well-preserved in the archaeological record. Although the architecture of even such well-documented regions as the Corinthia remains only fragmentary, sufficient evidence nevertheless exists to offer some informed speculation on the relationship between various contemporary monumental buildings.

The relationships between the 6th-century buildings in Corinth provide some of the only evidence for the local impact of large-scale, imperiallyfunded construction. A whole series of 6th-century buildings coincide with Justinian's growing influence over religious institutions and his efforts to advertise his authority through church building. The six major Late Antique basilicas arrayed around the city of Corinth represent part of a monumentalized discourse of authority contemporary with imperial involvement in the region (Map 1). ${ }^{5}$ Based on the present state of our

\footnotetext{
4 Given 2004; Kardulias 1995.

5 Pallas 1990. For more recent summaries and discussion see Gregory 2010; Sanders 2005 a.
} 
knowledge, these buildings appear to represent a roughly contemporary phase of large scale, monumental, 'Early Christian' type architecture in the Corinthia. There is little convincing evidence for earlier Christian buildings, and later Early Byzantine structures were either on a much smallerscale or were simply the later phases of 6th-century monuments. ${ }^{6}$

This section will consider the context and implications of the 6thcentury building boom around the city of Corinth and make three interrelated arguments. First, I suggest that the construction of numerous churches was less a functional response to a growing Christian population and more of a response to increased imperial investment in the region. Then, I show how this investment makes it possible to trace the aesthetic influences between ecclesiastical architecture and other contemporary buildings around Corinth. Finally, I argue that some decorative and architectural choices in the 6th-century churches may indicate efforts to produce local distinction or even to manifest resistance to imperially funded monuments.

The size and architecture of the 6th-century churches represents one of the more obvious characteristics of the 6th-century Christian city and its territory. It seems probable that these churches replaced a less monumental group of earlier structures dedicated to Christian worship. Earlier phases of Christian architecture may have stood in the countryside, perhaps associated with the property of the local elite, rather than clustered around the urban core. In fact, work across the Corinthia over the past 50 years has produced evidence for at least a half-dozen unexcavated Early Christian period churches which could have a $5^{\text {th }}$ century date. ${ }^{7}$

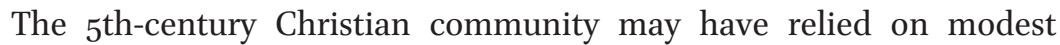
rural churches or even less imposing structures for their ritual and social needs. The presence of known, but unexcavated Christian buildings throughout the countryside provides sufficient evidence to discourage arguments that see the absence of churches as a sign of a small or underdeveloped Christian community. ${ }^{8}$ The presence of small Christian sites may, in fact, provide evidence to support the recent work of Bowes on the role of villa and private churches in the Christian communities in the Late Antique Mediterranean. ${ }^{9}$ Based on evidence from across in the

6 The obvious examples of probable late 6th or early 7 th-century buildings in the Corinthia are the basilica on Temple Hill and the small church on Acrocorinth.

7 Gregory 2010.

8 Sanders 2005a, 441; Sweetman 2010, 207-10, 241-44.

9 Bowes 2008. 
Mediterranean, Bowes has observed that Late Antique local aristocrats cultivated Christian communities in their extra-urban and sub-urban villas which typically stood apart from the political space of the ancient city's urban core, the church's institutional authority, and the need for monumental, public architecture. ${ }^{10}$ While there is no specific evidence for this practice in Greece, the prevalence of villas in the countryside provides at least one necessary precondition for this kind of arrangement. From the 4th century, the significant number of Late Roman villas in the Corinthia suggests that a kind of villa culture existed in the region. A similar shift of political, social, and economic capital to the countryside also occurred in the neighboring province of Epiros where Bowden demonstrated that rural villas were particularly common, ${ }^{11}$ and, at the same time, that monumental Christian architecture largely postdated other evidence for the appearance of Christianity. ${ }^{12}$ While the evidence for a villa-based Christianity in Epirus or the Corinthia remains circumstantial, the practice elsewhere reminds us that the appearance of monumental Christian architecture is as likely to represent the changing fortunes of the institutional church as it is to represent the expansion of the size or significance of local Christian communities. In other words, the construction of monumental churches around the urban core at Corinth could well mark out a shift in how Christianity was expressed locally rather than the growth of the Christian community in absolute terms. Monumental churches could, for example, demonstrate an interest among the local ecclesiastical elite in appropriating the traditional, monumental urban core as a challenge to less centralized expressions of Christian authority.

In this context, then, the 6th-century Corinthian basilicas with their imposing size, opulent decoration, and distinctive architecture present an architectural conversation extending beyond the basic functional needs of Christian community. ${ }^{13}$ These buildings would have likely stood out in size and decoration from their $5^{\text {th }}$ century predecessors and may have represented the emergence of monumental architecture to manifest authority in Corinthian society.

10 Pettegrew 2006, 331-52; Rothaus 1994.

11 Bowden 2003, 59-82.

12 Bowden 2003, 110; Rothaus 2000, 96; see Trombley (2001, 283-32) for a more guarded assessment of the growth of the Christian community in Athens and Attica and its relationship to church building.

13 Pallas 1977, 165-71 for a brief summary; Slane and Sanders 2005. 
The large-scale expansion of monumental Christian architecture in the 6th century Corinthia provides a basis for reconsidering the most impressive of the 6th-century churches, the Lechaion Basilica, which stood in the center of Corinth's western harbor town (fig. 8.1). This building is particularly significant because its extensive use of Proconnesian marble, elaborately decorated column capitals and floor treatments, and vast size suggests that the church was an imperial foundation. ${ }^{14}$ Initially dated by the excavator Pallas to the late 5 th to early 6 th century, the revised ceramic chronology offered by Slane and Sanders recommends a mid to late 6th century date for this building's construction. ${ }^{15}$ The combination of a mid to late 6th century date and opulent décor makes it possible to see this building as part of Justinian's larger building project both in the region and across the empire.

Despite the size and significance of this building, there is no contemporary textual evidence for the church. As a result, the only evidence for the impact of this building on local residents comes from its influence on the architecture of nearly contemporary structures in the region. Sanders has suggested that some aspects of the Panayia Bath as well as other small bathing establishments in the city of Corinth show similarities to the baptistery at Lechaion Basilica. ${ }^{16}$ The Lechaion baptistery and the

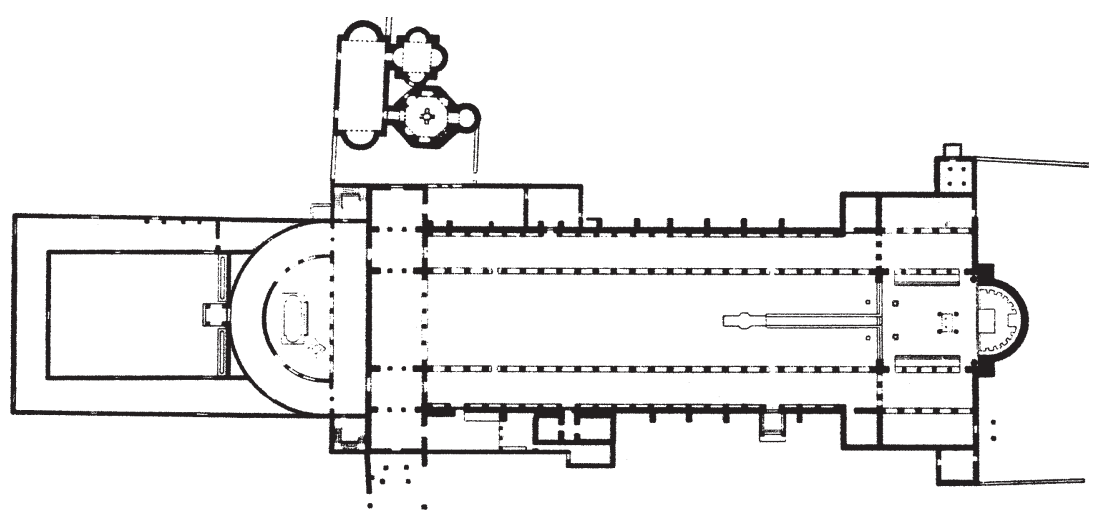

100 meters

Fig. 8.1. Plan of the Lechaion Basilica. Drawing by J. Herbst after Dimitrios Pallas.

\footnotetext{
14 Sanders 2005a, 439. Pallas 1979, 95-96.

15 Sanders 2005a, 439; Pallas 1977, 171.

16 Sanders 1999, 474-75.
} 
Panayia Bath are probably close contemporaries (fig. 8.2), and baptism and bathing share longstanding symbolic and architectural associations. ${ }^{17}$ As a result, an audience might have been predisposed to recognize the similarities between the two buildings; both have apsidal halls that led to two-chambered spaces, and both feature an octagonal core which opens onto additional chambers on four of its sides.

While finding parallels for octagonal baptisteries in Late Antiquity is not a particularly challenging task, it is worth noting that there are also clear parallels between the Lechaion baptistery and the perhaps contemporary 'Small Baptistery' at Agia Sophia in Constantinople. ${ }^{18}$ In Corinth itself, an octagonal structure associated with the so-called amphitheater church just inside the Kraneion gates of the city might be another baptistery. Pallas identified an ionic impost capital similar to those at Lechaion nearby and concluded that this might be a church or martyrium. Until this building is documented by excavation, its architectural and chronological

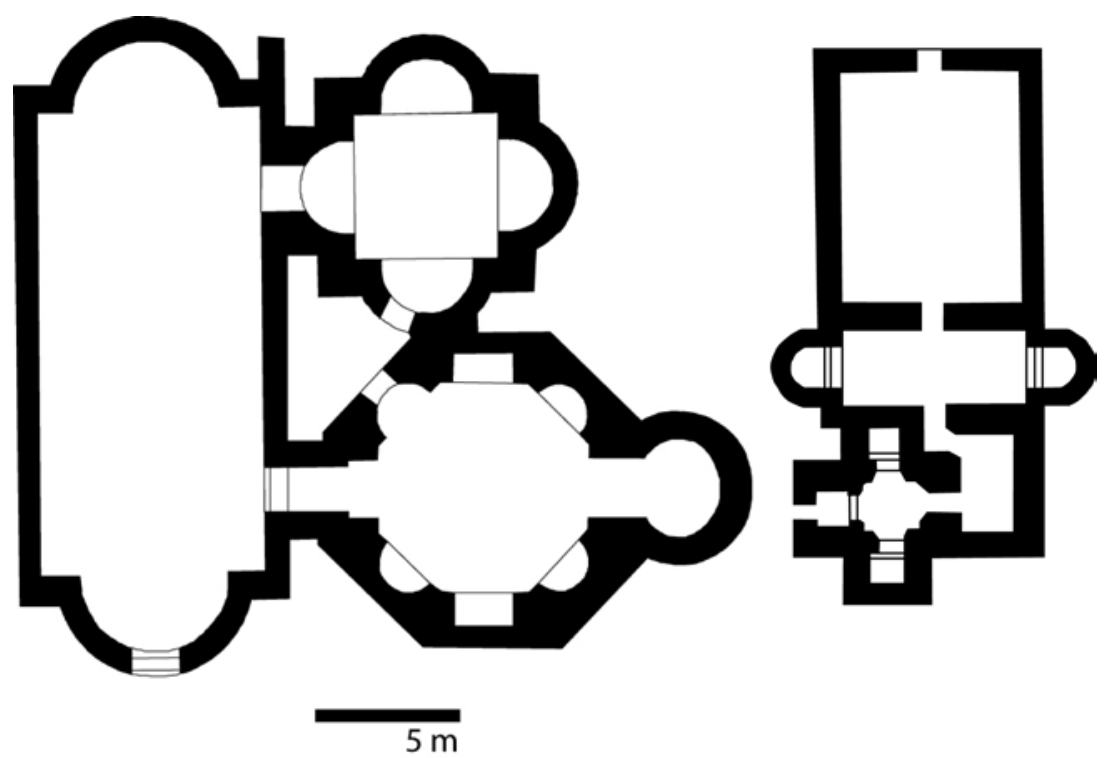

Fig. 8.2. Plans of the Lechaion baptistery (left) and the Panayia bath (right). Drawings by author (after Sanders 1999, fig. 18).

17 Ristow 1998, 20-23.

18 Dark and Kostenec 2006. 
relationship to other buildings in the region will remain obscure. The octagonal shape, however, and fragmentary architectural sculpture makes it tempting to imagine another 6th-century basilica in the area. ${ }^{19}$

The influence of the Lechaion Basilica also extended to a nearby nymphaion situated just over a kilometer to the northeast of the building. ${ }^{20}$ The initial phase of this structure appears to date to the Roman period, but coins of Justinian and Justin date a significant rebuilding to the 6th century. ${ }^{21}$ There are clear similarities between the opus sectile floors preserved at the nymphaion and those present at Lechaion. Another parallel comes from the architectural marble associated with the 6th-century rebuilding of the nymphaion. Both buildings featured impressive verde antico columns, and more importantly, there are at least three well-preserved ionic impost capitals from the site that look identical to those at the Lechaion Basilica. The similarities with the decoration of the nymphaion suggest that some of the marble architectural elements may have been produced by the same crews who worked on the Basilica. This is particularly significant for the appearance of three unpublished ionic impost column capitals from the nymphaion, a type which is exceedingly rare in non-ecclesiastical contexts. ${ }^{22}$ In fact, in Vemi's catalogue of published ionic impost capitals from Greece, there is only one such capital from a non-ecclesiastical building. While the precise function of the nymphaion remains unclear, ${ }^{23}$ the similarities in decoration between the two sites hints that the nymphaion enjoyed some relationship with the grandiose nearby church. It may be that the nymphaion served to advertise the imperial connections of a wealthy local resident, to support the prestige of the ecclesiastical hierarchy, or to serve as a stopping point for travelers along the coastal road on the approach to the church at Lechaion. In any context, the Justinianic date of the nymphaion coincides with the revised dates of the Lechaion Basilica and provides another example of the influence of this monumental building.

The most obvious buildings to reflect the function and architecture of the Lechaion Basilica are the other 6th-century basilicas around Corinth. While the chronological relationship between these buildings remains

19 Sanders 2004, 185.

20 Philadelpheus 1918; Stikas 1957.

21 Stikas 1957, 93-94.

22 Yegül $(1974,266)$ noted that the impost capitals from non-ecclesiastical context at Sardis and from the Palace in Constantinople did not feature crosses; the ones in Thessaly and the Corinthia do.

${ }^{23}$ Vemi 1989, no. 116; Soteriou 1939, 59-6o. 
difficult to assess, Pallas argued that the Corinthian churches, nevertheless, shared sufficiently similar features to be considered as a group. ${ }^{24} \mathrm{He}$ based his arguments on the cluster of possible liturgical annexes around their western end, their similar proportions of length to width, and their vaguely anthropomorphic shape. Even without Pallas's typological arguments, it is certainly possible to see the great Lechaion Basilica in the plans of both the Kodratos and Skoutelas Basilicas, and to a somewhat lesser extent in the preserved remains of the Kraneion Basilica.

Architectural similarities among the 6th-century Corinthian basilicas also highlight the differences between them. In this region, the Kraneion Basilica stands out as a notable exception to local patterns (fig. 8.3). At the Kraneion Basilica, heavy piers separated the aisles from the main nave ( $1.80 \mathrm{~m}$ wide $\times 0.85 \mathrm{~m}$ deep; against $1.80 \mathrm{~m}$ wide openings). ${ }^{25}$ This difference in how the nave was separated from the flanking aisles almost certainly had an impact on a visitor to a Corinthian basilica. The Lechaion Basilica, in contrast, followed a more traditional pattern by separating the nave from the aisles by a series of columns supporting arches that sprung from ornate ionic impost capitals. It appears that most of the columns in this nave colonnade were imperially-sourced Proconnesian marble with its imperial connections and the ionic impost capitals are sufficiently regular in design to suggest an imperial work crew. The absence, then, of a marble colonnade at Kraneion would have marked this church as distinct from its near contemporary at Lechaion. If we regard the use of Proconnesian marble and carefully-wrought ionic impost capitals in the nave colonnade at Lechaion as markers of the building's imperial funding, then the absence of such a colonnade at Kraneion may have served to distinguish this church and perhaps its source of patronage from the massive Lechaion Basilica.

This inconsistency in one of the primary areas for display in Late Roman basilica-type churches may have had particular significance in the context of the Greek liturgy. In most reconstructions of the Greek liturgy, the congregation stood in the aisles leaving the main nave open for liturgical movements by the clergy. ${ }^{26}$ The importance of clerical processions to the early Byzantine liturgy influenced the basic design of basilica-style churches and transformed the long axis of the church into a processional

\footnotetext{
24 Pallas 1979, 93-142.

25 Shelley $1943,172$.

26 Matthews 1971, 123-25; Sanders 2005a, 440-41.
} 


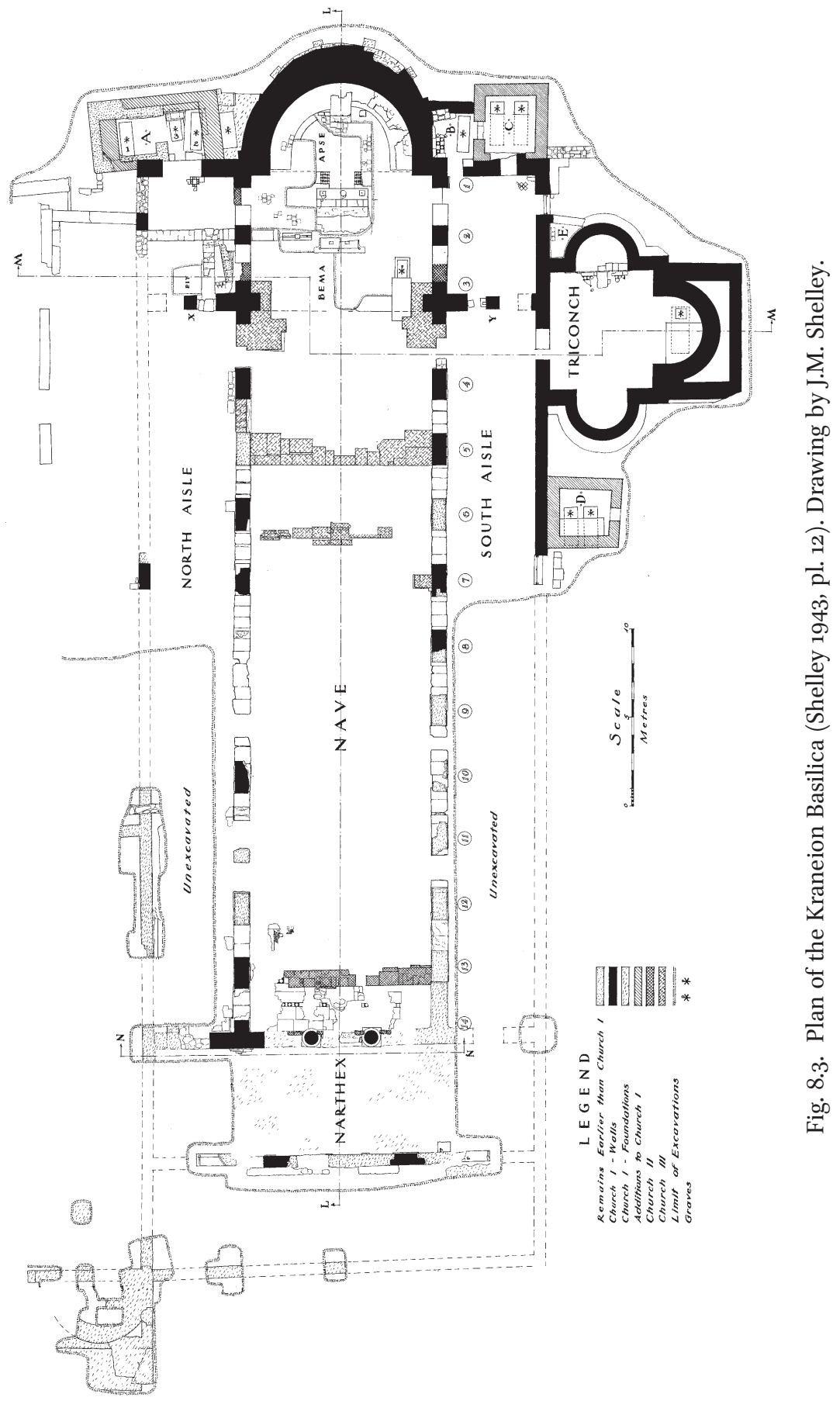


way. The colonnades and other barriers that separated the central nave from the flanking aisles structured the experience of viewing the processions and likely separated the clergy, who processed toward the more sacred eastern end of the church building, from the congregation who watched the progress of the clergy.

Thus, in a ritual context, the colonnade served to frame the perspective of the congregation as they watched the liturgical proceedings. The contrasting perspectives offered by the Lechaion Basilica and the church at Kraneion would not have been lost on even the most casual observer. Moreover, the importance of the processions to most Late Antique liturgies made the processional axis of the church a particularly important area for display. This accounts for the imposing colonnade of imported marble columns at Lechaion which represented a major commitment of resources, wealth, and decorative flourish. In contrast, the absence of an elaborate nave colonnade at Kraneion, then, literally reframed the viewing of the liturgy and suggested that the wealth and privilege communicated by the Lechaion colonnade formed just one part of a monumentalized discourse of religious status.

The appearance of monumental basilica-style churches in the neighborhood of Corinth in the 6th century had a clear impact on local architecture across the region. The architectural influence of the Lechaion Basilica extended to include buildings without clear religious functions, suggesting that church buildings represented more than merely ritual space for the community, but also served to shape local ideas of prestige as well. If the Lechaion Basilica was built with imperial funding, then its local impact is clear evidence for the effect of imperial building policy in the Corinthia and suggests that some individuals or groups in the Corinthia saw associating with a prestigious manifestation of imperial policy to be a good thing and extended the influence of the emperor's authority into the nearby landscape. In contrast, the difference between the Lechaion Basilica and the apparently contemporary Kraneion Basilica might well represent one limit to imperial influence in the vicinity of Corinth.

\section{Labor, Production, and Power in the 6th-Century Landscape}

While the elaborate basilicas that dotted the 6th-century landscape were architectural focal points of the Late Antique Corinthia, the influence of the 'building boom' extended beyond efforts to emulate ecclesiastical architecture. Procopius tells us that Justinian repaired the Hexamilion fortification 
which had fallen into ruins. Justinian may have also repaired or refortified the city wall of Corinth. ${ }^{27}$ Survey archaeology has documented what appear to be contemporary developments in the construction across the Corinthian countryside. The material present in the countryside suggests that the rural zone of the Isthmus saw a new wave in elite rural habitation perhaps associated with the intensification of agriculture and local prosperity. The large-scale 6th-century investment in the region by both the imperial authorities and local residents must have made a significant impact on the economy, settlement, and experience of life in the Corinthia.

The 6th-century building boom across the Corinthia demonstrated the use of monumental architecture to communicate imperial authority and resistance across the region. As I have argued, fragments of this monumentalized discourse of authority are visible in the influence of the Lechaion Basilica, but its effects extended beyond stylistic or architectural influences and contributed to the productive and experiential landscape of the region as well. The construction of such imposing buildings, whether in collaboration with the emperor or in response to imperial initiatives, undoubtedly taxed the resources of the local elite and involved the labor of numerous ordinary Corinthians. Traditionally, the study of large-scale building projects has emphasized the role that it played in communicating identities and structuring relationships among both local elite and external authority. While there is little doubt that elite motives played a central role in structuring the ancient architecture of a region, the act of constructing the physical monuments also engaged the physical bodies of a significant number of Corinthians. The economic impact of the monumentalization of authority on both elite and non-elite Corinthians linked patterns of labor, production, and consumption to the experience of an increasingly monumentalized landscape. The result was a dynamic, heterogeneous landscape laced with the potential for accommodation and resistance. ${ }^{28}$ The construction of power and authority was not monolithic and provided new opportunities for Corinthians to use imperial investment in the region to promote their own position in society.

The most ambitious non-ecclesiastical project in the region was likely the work to repair or reinforce both the Hexamilion and the city wall of Corinth. Inscriptions associated with the Hexamilion Fortress and Procopius's account of Justinian's work in the area make clear that these

27 Procop. Aed. 4.2.27-28; 4.1.2; Gregory 2000, 105-15.

28 Paynter and McGuire 1991. 
projects represented imperial interest in the Corinthia. While we will consider the Justinianic inscriptions in greater detail in the final section of the chapter, these texts named the emperor specifically and alluded to the deployment of an official named Victorinus who may have been a specialist in fortifications in the Balkans and beyond. ${ }^{29}$ Even if the 6thcentury wall around the city itself was, as Sanders has argued, much smaller than previously suggested, the refortification of the city nevertheless represented a serious and highly visible commitment to the community. ${ }^{30}$ Kardulias and Gregory have both shown that the financing and personnel required for these projects would have provided employment to local laborers, influenced the distribution of wealth in the local economy, and likely brought troops or skilled workmen into the region. ${ }^{31}$ The scale of the undertakings, particularly those associated with the repair of the Hexamilion, suggests that these refortification projects would have affected almost the entire Corinthia. Moreover, the presence of monumental inscriptions associated with at least some of these fortifications tied imperial munificence to important and highly visible features in the Corinthia. Finally, city walls and the massive structure of the Hexamilion shaped how residents of the Corinthia experienced travel through the region in highly visible and tactile ways.

The renewed fortification walls across the Corinthia were not merely spectacles designed to impress local residents with the presence of the imperial authority. ${ }^{32}$ Local Corinthians, irrespective of political or religious predilections would have contributed to the physical construction of the Hexamilion Wall and the maintenance of any associated garrisons. Epigraphical evidence shows that laborers in the Late Antique Corinthia were organized as they were elsewhere in the empire. ${ }^{33}$ The organization of labor into guilds or less formal groups linked individual identity, at least in part, to participation in the local economy and local politics. It may be that this organization left faint traces across the monuments of the Corinthia suggesting that the building boom of the 6th century did more than simply project elite power into the region, but also provided a space for more ordinary Corinthians to negotiate their own place within the monumental discourse of authority. As possible evidence for this process,

\footnotetext{
29 Feissel 1990, 136-46.

30 Slane and Sanders 2005, 193.

31 Kardulias 1995 and 2005.

32 For recent work on this topic in the west, see Dey 2010.

33 M.B. Walbank 2010 for the most recent summary.
} 
Sanders has reported that graffiti of fish were made in the wet mortar of the Lechaion Basilica, the Panayia Bath in the city of Corinth proper, the Hexamilion Wall, as well as several other places in the vicinity of Corinth. ${ }^{34}$ These markers in the mortar of the exterior wall of the basilica would have been visible for only a short period of time as they would have almost certainly been covered with either a layer of finer stucco or the surrounding ground level when the building was completed. The symbol of the fish may have religious significance as it was one of the earliest symbols associated with Christianity. We have no idea whether these symbols were set to mark out these buildings as 'Christian' (as if this was necessary for the Lechaion Basilica), to serve some kind of as apotropaic function or to mark the work of a particular crew of laborers. These modest graffiti might well suggest that the same groups of workers or, perhaps, the same organization provided labor for both buildings.

Whatever their function, however, it is clear that the monumental architecture of the Corinthia not only projected power across the region and onto (and through) the bodies of laborers, but it also provided a new context for the everyday actions of Corinthian workers. The subtle traces left by individuals working on the walls provide a glimpse of the physical labor responsible for the construction of imperial authority on the Isthmus. The appearance of the graffiti fish in inconspicuous places on a number of contemporary buildings suggests a division between the explicit message made by the architecture and decoration and the simpler, hidden graffito. The understated character of these graffiti would be consistent with subtle expressions of resistance from individuals in highly asymmetrical power relations. ${ }^{35}$ Even if these graffiti are not the marks of resistance, they demonstrate how the local investment in imperial authority created a heterogeneous space for the expression of corporate identities.

Additional evidence for the impact of imperial influence on labor and production on the Isthmus of Corinth comes from Procopius. Procopius was clearly aware that building and providing garrisons for Greece had an impact on labor and production. For example, he praised Justinian for constructing granaries near Thermopylae to provide food for garrisons stationed there. ${ }^{36}$ As Given has noted, the act of collecting or contributing taxes in kind represents a highly visible and physical means to link the

34 Sanders 2005a, 428; Athanasoulis 1998.

35 For more on the archaeology of resistance see: Paynter and McGuire 1991; Silliman 2001; Scott 1985, 1986.

36 Procop. Aed., 4.2.14. 
act of agricultural production to the power of the dominant authority. ${ }^{37}$ It seems reasonable to conclude that the stationing of garrisons around Corinth would have required a similar investment in granaries to supply the forces. While Procopius tells us nothing in his De Aedificiis of the local response to the creation of granaries or the construction of fortifications across Greece, he is less charitable in his Historia Arcana. In this text, Procopius blames Justinian and his lieutenant Alexander 'the Scissors' for taxing Greece so heavily to pay for garrisons that no public buildings could be constructed or games held even in Athens. ${ }^{38}$ Local responses to Justinian's investment in Greece likely fell between the neutral view presented in the De Aedificiis and the critical view of the Anecdota. The increased involvement of the emperor in the affairs of the provinces, nevertheless, makes it difficult to avoid Dunn's conclusions that the economic reorganization of Greece begun under Justinian had a significant impact on production and settlement in the region. ${ }^{39}$

Evidence that connects specific policies with settlement changes, shifts in patterns of agricultural exploitation, and other short-term economic changes often goes undetected in archaeological work conducted on the regional scale. Ceramic chronologies, particularly for the coarse and utility wares that played a key role in the regional economy, remain generally too imprecise to provide evidence for short-term shifts in economic activity. The Eastern Korinthia Archaeological Survey, however, produced several suggestive concentrations of 6th-century fine ware on the Isthmus that may hint at changes in the local settlement and consumption patterns by local residents (fig. 8.4). ${ }^{40}$ These concentrations consist of three of the most common middle to late 6th- century pottery forms: Phocaean Red Slip (or Late Roman C) Form 10 and African Red Slip Forms 103-105 and 99, which usually date to after 533 and the Byzantine reconquest of North Africa. These sherds appear in several clear concentrations of artifacts suggesting that they reflected some kind of cohesive activity areas. Moreover, the survey units with 6th-century pottery tend to lack diagnostic fine ware from earlier periods in Late Antiquity. This would seem to indicate that these areas saw an increase in investment or a change in function during the mid 6th century. Perhaps earlier, more industrial uses

37 Given 2004, 93-195.

38 Procop. Anecdota, 26.

39 Dunn 2004.

40 Pettegrew 2006 for the most detailed discussion of the Late Roman landscape. 
WILLIAM CARAHER

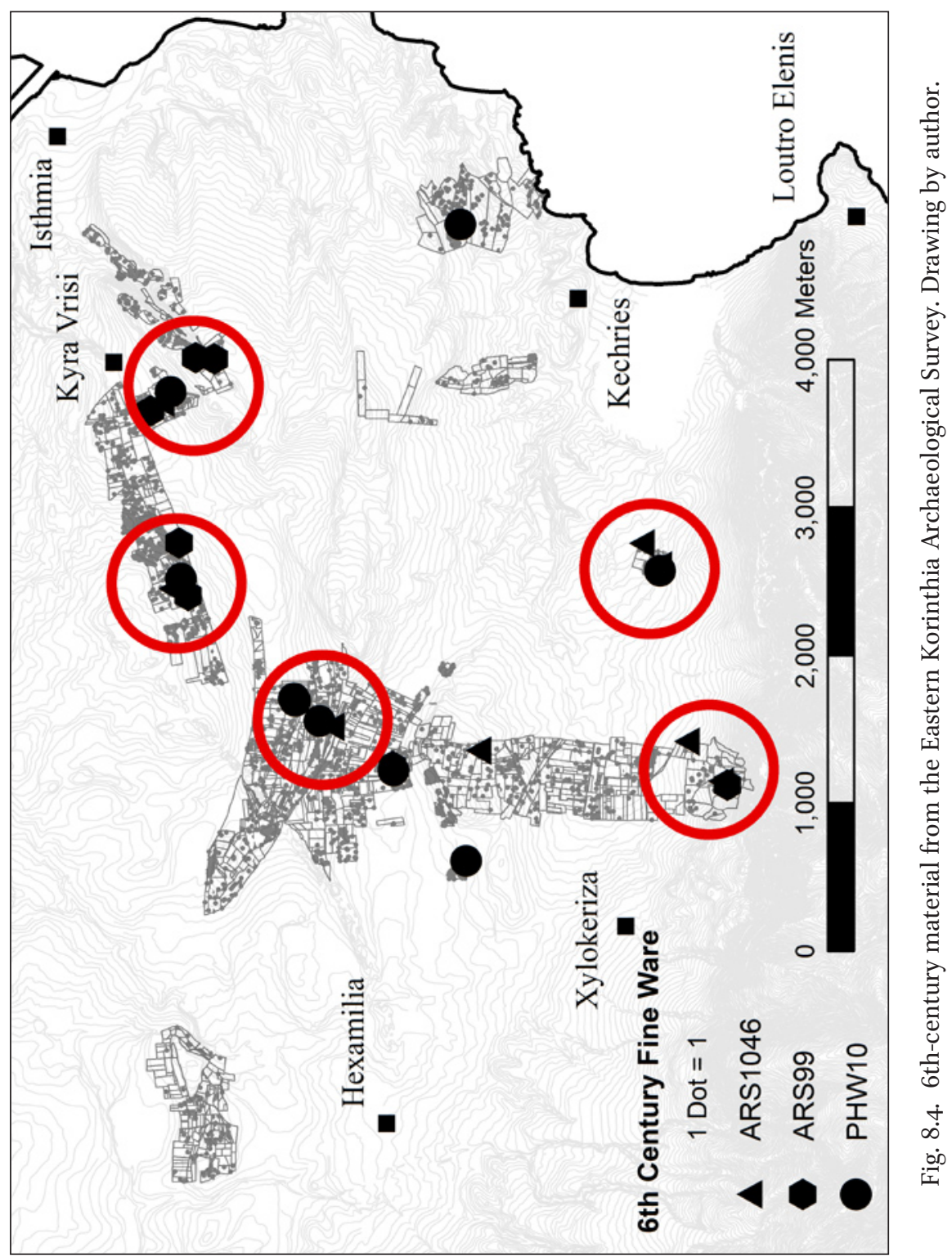


of the city's territory gave way to domestic activities where imported fine wares were more appropriate.

The evidence from this survey complements evidence from betterdocumented sites, such as the villa at Akra Sophia published by Gregory and the Southeastern Korinthia Exploration Project. ${ }^{41}$ Gregory dated the elaborate Akra Sophia villa to the second half of the 6th century on the basis of a fragment of amphora embedded in the mortar of a foundation and associated material. ${ }^{42}$ Like many of the concentrations discovered in the survey, there was little evidence to suggest that this villa was part of an expansion of earlier large-scale activity at the site, although the villa's foundations set into the bedrock may have obscured or obliterated evidence for earlier activity. While these scattered pottery finds do not provide us with enough evidence for our functional, political, or religious arguments, they do show that settlement patterns experienced some modest shift contemporary with a time of increased imperial and local investment in the monumental architecture of the region.

To sum up, the economic impact of the 6th-century building boom provides visible traces both of imperial involvement in the region and local responses in the rural territory and labor market of the Corinthia. Unlike the relationships among monumental buildings, which remained highly visible in the Corinthia landscape, the impact of imperial involvement on everyday life may have penetrated areas barely visible in the archaeological record but very much present in the daily experiences of Corinthians. In this context, subtle traces like the graffiti of fish or changes in settlement may represent acts of accommodation or resistance to external pressures.

\section{Ambivalence, Control, and Compromise in Inscriptions and Architecture}

The imperial investment in a building like the Lechaion Basilica and the particular attention to ritual space is consistent with imperial interests in liturgical space across the empire. Justinian's involvement in the affairs of the institutional church, however, did not end at the funding of

41 Gregory 1985, 416-19.

42 The associated pottery includes fragments of an imitation of a Phocaean Red Slip or Late Roman C bowl, a Phocaean Red Slip or Late Roman C Form 1oB, and an African Red Slip Form 99; all of which support a date in the later 6th century CE. 
monumental architecture, but extended to what Cameron and Nelson have referred to as the "liturgification" of society. ${ }^{43}$ This interest in expanding the role the liturgy in Late Roman society coincided with Justinian's efforts to seek political and theological compromise. Procopius's De Aedificiis, for example, emphasized the strong religious dimension to Justinian's building projects, and Justinian's own writing showed a commitment to theological and ecclesiastical affairs that finds parallels with his increasingly public and monumentalized discourse of authority. ${ }^{44}$ Moreover, as this final section will show, these texts walk a fine and intentionally ambivalent line between potentially divisive statements of religious policy and a willingness to compromise with potential local practices.

The language present in the two Corinthian inscriptions associated with Justinian demonstrates how he brought together theology, the liturgy, and monumental architecture. While these texts are discussed in greater detail elsewhere, ${ }^{45}$ both texts used theologically loaded language to ask God and the Virgin to protect the emperor, his colleague Victorinus, and Greece. ${ }^{46}$

The first text likely comes from a gate in the Hexamilion Wall: ${ }^{47}$

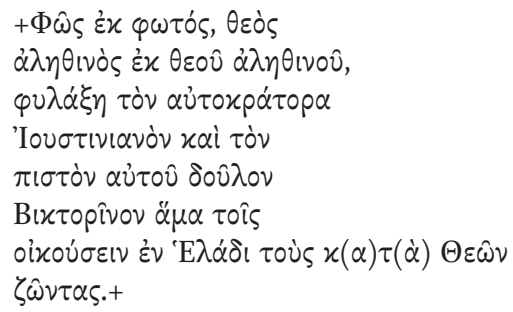

Light of Light, True God of True God, guard the emperor Justinian and his faithful servant Victorinus along with those who dwell in Greece living according to God.

The second text, now in Verona, comes either from the wall of the city of Corinth, or perhaps more plausibly, from another gate in the Hexamilion: ${ }^{48}$

43 Nelson 1976, 101-5; Cameron 1979, 15-17.

44 Fowden 1995, 549-67; Cameron 1985; Gray 1979.

45 Caraher forthcoming.

46 IG IV 204; IG IV 205.

47 IG IV 204; Corinth VIII.3. no. 508, 168-69; Isthmia V, 12-13, no. 4.; Feissel and Philippidis-Braat 1985, 279-80, no. 16; Monceaux 1884, 277-78; Skias, 1893, 123; Lambros 1905, 268-69; Lampakis 1906, 46-47; Groag 1949, 79; Bees 1941, 1-5, no. 1.

48 IG IV 205; Bees 1941, 5-9, no. 2; Feissel and Philippidis-Braat 1985, 281-82, no. 18; Guarducci 1978, 327-30, no. 2; Isthmia V, 14 no. 5 . 


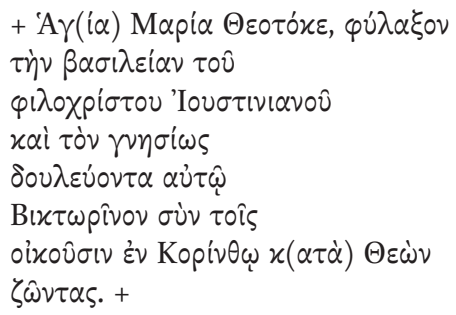

Holy Mary, Theotokos, safeguard the empire of the Christ-loving Justinian and his faithful servant Victorinus, along with those who dwell in Corinth living according to God.

The texts are inscribed in tabula ansata fields, and the size, content, and shape of the inscriptions suggest that they were probably built into a gate, perhaps above the arch, as was common elsewhere in the Mediterranean during the Justinianic period. ${ }^{49}$ Scholars have generally dated these texts to the early 550 s based on the absence of Theodora from the texts.

A date in the mid 6th century places these inscriptions amidst a series of increasingly hostile political and theological clashes with the church in the West which ultimately emerged over the course of the Three Chapters Controversy in the 540s and 550s and culminated in the Second Council of Constantinople (553). ${ }^{50}$ This environment may provide a context both for the text's refusal to name any local elites and for its clear reference to contemporary theological controversies. Even under Justinian, local elites regularly appeared in texts commemorating monumental construction in the provinces. ${ }^{51}$ In the Corinth texts, the absence of any mention of local elites might well imply that these inscriptions indicate projects sponsored directly by the emperor. This casts light, then, on references to the Theotokos and the Nicene-Constantinopolitan Creed, which both evoked some of the emperor's theological imperatives and suggested the concomitant spread of the imperially-sponsored Constantinopolitan liturgy. The presence of the Nicene-Constantinopolitan Creed in the inscription discovered at Isthmia likely evokes the Constantinopolitan liturgy where

49 There are particularly close parallels from North Africa: Pringle 1981, 319 no. 4, 327 no. 29; and from Syria: IGLSyr I.145, 146, 147. See also an inscription of similar date originally in the city wall of Byllis in Albania, SEG 35.530-33 naming Viktorinos and inscribed with similarly sized letters.

50 For a good summary of issues related to the Three Chapters controversy, see Chazelle and Cubitt 2007.

51 Pringle 1981, 89-91; Croke and Crow 1983, 147-48. 
the Creed was regularly read by the 6th century. ${ }^{52}$ The reference to the Theotokos in the second contemporary inscription from the Isthmus may represent a theological extension of the references in the Isthmia text. In fact, these texts may have worked together to embed a theological argument within the physical space and monuments of the Corinthia. After all, if Christ was "Light from light, true God from true God," then it made some sense to see Mary as the Theotokos.

The link between Mary as the Theotokos and the Creed transferred concepts from Justinian's own theological writings to the Corinthia. The same link between the Creed and the Theotokos appears in his own writings. The clearest example of this comes from Justinian's Letter on the Three Chapters which E. Schwartz suggested was a response to a poorly known 'synod' of Eastern Illyricum held in the mid- $5405 .{ }^{53}$ This text responded, in particular, to letters from a bishop alleging that Justinian's rejection of the Three Chapters was a form of Nestorianism. Justinian's response took pains to demonstrate how Mary's status as the Theotokos was inseparable from the incarnation of the Divine Logos as Christ which he explicitly articulated as "Light of Light." He then reversed the charge and argued that the author of the letter was himself a Nestorian, and this represented the dangers of the work of Theodore of Mopsuestia whose texts he condemned amidst the Three Chapter debates. Justinian's work followed closely the work of the called Neo-Chalcedonian theologians who drew heavily on the works of Cyril of Alexandria. ${ }^{54}$

This debate, however, extended beyond theological polemics, and appeared in less theological texts like the near contemporary encomium of Corripus, In Laudem Iustini Augusti minoris. This text celebrated Justin II's ascension to the throne in 565 , encapsulated many of the efforts at theological reform by Justinian I. It began with a vision of the Theotokos, and concluded with long passage describing Agia Sophia in Constantinople in terms of the Creed. ${ }^{55}$ The tendency to link Mary as Theotokos to an argument for the incarnation using the Nicene-Constantinopolitan Creed provides a context for the invocations of both the Corinth inscriptions and relates these texts clearly to the ongoing debate concerning the status of the Three Chapters.

52 Kelly 1950, 348-49.

53 Schwartz 1939, 115 .

54 PG 86.1048; Gray 1979; Justinian, On the Person of Christ: The Christology of Emperor Justinian. Translation by Wesche 1991, 119-20 and throughout.

55 Cameron 1976. 
By foregrounding theologically sensitive language in these two Corinthian inscriptions, Justinian emphasized a growing interest not only in extending imperial authority over matters of theology, but specifically in exerting a concerted influence over the church in the West. ${ }^{56}$ Neither of the texts referenced above would fit within the theological context of Western, that is Papal, theology. In fact, the Roman church neither venerated Mary as the Theotokos nor saw the Nicene-Constantinopolitan Creed as an important public text until its inclusion in the liturgy in the 1oth century. ${ }^{57}$ At the same time, these texts drew upon concepts on which there was general agreement in the West and East, and in particular reinforced the imperial loyalty to ecumenical symbols of Chalcedon, Ephesos, and ultimately Nicaea.

The Constantinopolitan and imperial liturgy also made its presence felt locally through the position of the centrally placed ambo in the church at Lechaion. The ambo was an elevated pulpit from which the presiding clergy read the Gospels. The central placement of this feature is unusual in Greece and was incompatible with the organization of the early liturgy in the West. ${ }^{58}$ In Constantinople, the solea, a walkway protected by balustrades, provided access to the ambo. It allowed the clergy to move freely to the ambo without being crushed by the press of congregation in the main nave. ${ }^{59}$ Ambos in Greece, in contrast, were offset to either the north or south of a church's main axis and generally lacked the solea. ${ }^{60} \mathrm{In}$ fact, the solea was redundant in Greece, and at the Lechaion Basilica in particular, because intercolumnar parapet screens set atop a high stylobate separated the aisles from the main nave and the congregation from the main processional space of the clergy. In this arrangement, the specific function of the centrally-placed ambo and the solea, as well as its relationship to specific liturgical movements is perhaps less significant than the architectural allusion to the Constantinopolitan liturgy in the arrangement of the nave at Lechaion. The use of Proconnesian marble, as we noted above, completed the architecture experience by framing the scene of the liturgy with imperial opulence.

\footnotetext{
56 Markus 1979, 277-306; Sotinel 1992, 2005, 267-90.

57 Kelly 1950, 356-57.

58 For the liturgy in Greece see: Soteriou 1929; Orlandos 1957; Pallas 1979/1980; Pallas 1984; Mathews 1971, 119-21.

59 Jakobs 1987, 255-56; Xydis 1947; Mathews 1971, 110.

60 Jakobs 1987.
} 
The textual sources for the church of Corinth are particularly scant, but perhaps in the context of the epigraphy and architecture they can contribute slightly to our picture. The Corinthian church was probably out of communion with the Bishop of Constantinople until the early decades of the 6th century and the resolution of the Acacian schism. The aftershocks of this controversy probably echoed and ensured that the emperor's religious policies did not garner enthusiasm at least among the ecclesiastical elite. In 536, the bishop of Corinth overtly supported a visit of Pope Agapitus to the Capital to depose the monophysite-leaning Patriarch Anthimus by sending two deacons presumably to represent his See. ${ }^{61}$ In a more circumstantial association, Pseudo-Gregory in his Dialogues has militantly proChalcedonian Bishop Datius of Milan stop through Corinth on his way to the Capital in $544 .{ }^{62}$ It should go without saying that a major route from the West passed through Corinth in Late Antiquity; ${ }^{63}$ so it may be significant that the city of Corinth is mentioned by name. By the Council of Constantinople in 553, only four bishops attended from the province of Achaea: Megara, Opus, Aigio, and Porthmos on Euboea. ${ }^{64}$ While the subscription list for the council remains problematic, the absence of Corinth - the metropolitan church of Achaea - suggests that support for the Council's decision did not necessarily follow along the lines of the ecclesiastical hierarchy.

The textual sources, the inscribed texts from the Isthmus, and the arrangement of liturgical furnishings presented an ambivalent message regarding the relationship between the emperor and the local community. On the one hand, imperial interests and the allusions to imperial liturgy of Constantinople are unmistakable; on the other hand, references to local practice and sensitivities to local beliefs grounded imperial authority in a Corinthian context. The ambivalence in the sources of the imperial attitude toward Corinth may capture precisely the kind of 'internal friction' that Elsner identified as traces of resistance.

\section{Conclusions}

The political position of the Corinthia in the 6th century gives us reason to consider the archaeology of the territory in a new light. The increased

\footnotetext{
61 ACO III, 29.16, 127.39, 163.13, 171.30.

62 Ps.-Gregory, Dialogues, 3.4.

63 McCormick 2000, 69-72.

64 Price 2009, 294; Chrysos 1966.
} 
imperial investment in the territory and the corresponding building boom reflects the emergence of a monumental discourse of authority during a time when imperial policy toward the Western empire took on an expansionist posture. Evidence from inscriptions confirms that imperial interest in the Corinthia was not free from theological and, most likely, ecclesiological interests, and this position seems appropriate considering Corinth's status as the seat of the bishop of Achaia.

At the same time, the energy expended to present imperial authority in the region preserved subtle traces of what might be local critique. The text of the inscriptions and the organization of liturgical space within the Lechaion Basilica communicated an ambivalence that charted a course between a brash assertion of imperial policy and the accommodation of local practices. The graffiti made in the external walls of local buildings, the responses of the local economy to the requirement of monumental construction and garrisons, and the influence of important buildings across the Corinthia present subtle clues as to how the Corinthian community responded to increased imperial involvement. While none of this provides explicit and incontestable evidence for traditional or widespread forms of resistance in the Corinthia, it opens up space to consider the limits of imperial authority and local accommodation during times of conflict.

Mediterranean archaeology has traditionally emphasized artifacts associated with the economic elite. Monumental architecture, fine table wares, epigraphy, and the long shadow of literary texts, has produced a world where evidence for inequality and resistance will appear only in the margins. By reading against the grain of both existing scholarship and evidence, it is possible to identify the potential for resistance in the Late Antique Corinthia. Only continued archaeological work and careful study of texts can determine whether this space for potential resistance is ultimately filled with the activities of autonomous human agents. 